\title{
Karakterisasi Gen KIF12 (Kinesin Familly 12) serta Hubungannya dengan Komposisi Asam Lemak pada Domba
}

\author{
Asep Gunawan ${ }^{1 *}$, Sarah Tazkya ${ }^{1}$, Kasita Listyarini ${ }^{1}$, Mohamad Yamin ${ }^{1}$, \\ Ismeth Inounu ${ }^{2}$, Cece Sumantri ${ }^{1}$ \\ ${ }^{1}$ Departemen Ilmu Produksi dan Teknologi Peternakan, Fakultas Peternakan IPB \\ Jl. Agatis Kampus IPB Darmaga, Bogor 16680 \\ ${ }^{2}$ Pusat Penelitian dan Pengembangan Peternakan, Jl. Raya Pajajaran Kav. E-59, Bogor 16151. \\ *Email korespondensi: aagun4780@gmail.com
}

(Diterima: 20-8-2018; disetujui 21-9-2018)

\begin{abstract}
ABSTRAK
Kinesin Family 12 (KIF12) merupakan gen yang terlibat dalam mediasi kaskade antioksidan dalam sel beta sebagai sebuah target intraselular dari kelebihan asupan lemak atau lipotoksit. Penelitian ini bertujuan untuk mengidentifikasi karakterisasai gen KIF12 melalui identifikasi keragaman dan asosiasi gen KIF12 terhadap komposisi asam lemak pada domba. Sampel domba yang digunakan sebanyak 35 ekor yang terdiri dari Domba ekor Gemuk (DEG) dan Domba Ekor Tipis (DET) masing-masing 20 dan 15 ekor. Titik mutasi gen KIF12 berada pada posisi g.9617965 C $>$ T. Identifikasi keragaman gen KIF12 dianalisis menggunakan Polymerase Chain Reaction - Restriction Fragment Length Polymorphism (PCR-RFLP) dengan menggunakan enzim BfaI. Hasil keragaman gen KIF12 bersifat polimorfik dengan ditemukan tiga genotipe yaitu CC, CT, dan TT. Hasil Uji chi square menunjukkan bahwa lokus KIF12 berada pada keseimbangan Hardy-Weinberg (HWE) pada pada DET, hal berbeda ditunjukakan pada DEG. Titik mutasi gen KIF12 berasosiasi secara signifikan $(\mathrm{P}<0.05)$ terhadap asam lemak jenuh $(\mathrm{SFA})$ asam laurik $(\mathrm{C} 12: 0)$, asam miristik $(\mathrm{C} 14: 0)$ and asam heptadenoik (C17: 0) juga asam lemak jenuh tunggal (MUFA), asam miristoleinik (C14: 1) and asam oleik (C18: 1n9c). Gen KIF12 memiliki potensi untuk digunakan sebagai penanda seleksi terhadap komposisi asam lemak.
\end{abstract}

Kata kunci: domba, asam lemak, KIF12, PCR RFLP

\section{ABSTRACT}

Kinesin Family 12 (KIF12) is one of gene which involved in mediates an antioxidant cascade in beta cells as an intracellular target of excess fat intake or lipotoxicitys. This study was aimed to identify the polymorphism and association of KIF12 gene as candidate gene for fatty acid composition in Indonesian sheep including fat-tailed sheep and thin-tailed sheep. The sample of sheeps used 35 heads consist fat-tailed sheep and thin-tailed sheep as many as each 20 and 15 samples. Identification of polymorphism of KIF12|BfaI gene were analyzed using Polymerase Chain Reaction - Restriction Fragment Length Polymorphism (PCR-RFLP). The results of polymorphism of KIF12 gene were polymorphic for three kind of genotypes of CC, CT, and TT. The chi square revealed that the locus of KIF12 was deviated in Hardy-Weinberg equilibrium (HWE) in fat-tailed sheep, but was in HWE in thin-tailed sheep. A SNP of KIF12 was associated $(\mathrm{P}<0.05)$ with saturated fatty acids (SFA) including lauric acid (C12:0), myristic acid (C14:0) and heptadecanoic acid (C17: 0 ) as well as monounsaturated fatty acids (MUFA), namely miristoleinic acid (C14: 1) and oleic acid (C18: 1n9c).The KIF12 gene was the potential to be used as a marker of selection for fatty acid compositions.

Keywords : sheep, fatty acids, KIF12, PCR-RFLP 


\section{PENDAHULUAN}

Domba merupakan salah satu ternak yang berkontribusi terhadap produksi daging nasional. Menurut DPKH (2017) kontribusi daging domba pada tahun 2016 sebesar 45.912 ton atau hanya sekitar $2 \%$ dari total konsumsi daging nasional. Angka ini masih tergolong kecil jika dibandingkan dengan produksi daging sapi yang mencapai 518. 484 ton. Salah satu penyebab rendahnya konsumsi daging domba diantaranya adanya persepsi masyarakat yang menganggap bahwa daging domba mengandung asam lemak tak jenuh tinggi dan tinggi kolesterol yang berimpilikasi negatif terhadap kesehatan.

Asumsi masyarakat mengenai daging domba tinggi asam lemak tak jenuh dan kolesterol perlu dibuktikan kebenarannya. Asam lemak berdasarkan ikatan rangkapnya dikelompokkan ke dalam tiga kategori (Wina dan Susana 2013) yaitu asam lemak jenuh (SFA), asam lemak tidak jenuh tunggal (MUFA), dan asam lemak tidak jenuh ganda (MUFA). Asupan tinggi dari asam lemak jenuh (SFA) dapat menyebabkan peningkatan kolesterol plasma, yang mengarah ke penyakit kardiovaskular (Alvarenga et al, 2015). Cheeke and Dierenfeld (2010) melaporkan konsumsi daging yang mengandung asam lemak jenuh (SFA) tinggi terutama asam laurat (C12:0) dapat mengakibatkan otot rentan terhadap resistensi insulin sehingga timbul hiperinsulinemia atau meningkatkan produksi kolesterol oleh hati. Upaya perbaikkan mutu genetik untuk menghasilkan domba dengan kandungan asam lemak tak jenuh tinggi, rendah asam lemak jenuh dan kolesterol merupakan salah satu alternatif solusi yang dapat ditawarkan bagi konsumen daging domba sekarang ini.

Komposisi asam lemak dan kolesterol merupakan sifat kuantitatif yang dipengaruhi oleh faktor genetik diantaranya lebih dari satu gen. Sifat perlemakan sendiri mempunyai nilai heritabilitas yang tinggi yaitu sekitar 0.26-0.6 yang berarti sifat perlemakan dipengaruhi oleh genetik cukup tinggi dan perbaikkan mutu genetik melalui seleksi sangat memengkinkan untuk dilakukan dengan baik (Kazakov et al, 1984). Salah satu seleksi yang dapat digunakan yaitu seleksi berbasis molekuler melalui identifikasi gen pengontrol asam lemak. Gen KIF12 (Kinesin Familly 12) merupakan gen penting yang diprediksi mengontrol metabolisme asam lemak.

Kinesin Family 12 (KIF12) merupakan salah satu gen yang terlibat dalam mediasi kaskade antioksidan dalam sel beta sebagai sebuah target intraselular dari kelebihan asupan lemak atau lipotoksit (Yang el al,. 2014). Kinesin sendiri merupakan protein yang termasuk dalam kelas protein motor (penggerak) yang ditemukan pada sel eukariotik. Penelitian Rai et al. (2017) menunjukkan bahwa kinesin mempunyai hubungan terhadap pengontrolan sekresi trigliserida dari hati. Belum banyak penelitian terkait gen KIF12 pada domba sehingga belum diketahui pasti fungsinya namun diduga mempunyai keterkaitan erat sebagai pengontrol komposisi asam lemak dalam daging domba. Penelitian ini dilakukan untuk karakterisasi gen KIF12 melalui identifikasi keragaman gen KIF12 dan asosiasinya terhadap asam lemak pada domba.

\section{MATERI DAN METODE}

\section{Ternak Domba dan Data Fenotipik}

Domba yang digunakan pada penelitian ini sebanyak 35 ekor yang terdiri dari domba ekor gemuk (DEG) dan domba ekor tipis (DET) masing masing sebanyak 20 dan 15 ekor. Domba dipelihara pada kondisi perkandangan dan pemberian pakan yang cukup terkontrol secara ad libitum. Umur domba yang digunakan berkisar antara 10-12 bulan dengan bobot potong sekitar $30 \mathrm{~kg}$. Semua prosedur penelitian mengacu pada peraturan dan rekomendasi dari Komisi Etik dan Kesejahteraan Hewa IPB (Nomor : 117-2018 IPB). Bagian loin diambil sebanyak $500 \mathrm{~g}$ untuk analisis asam lemak dan 30 mg untuk ekstraksi DNA.

\section{Analisis asam Lemak}

Analisis kandungan asam lemak dilakukan menggunakan bagian loin domba. Komposisi asam lemak dianalisis menggunakan standar AOAC (2012). Komposisi asam lemak yang diukur meliputi kandungan lemak, asam lemak jenuh (SFA), asam lemak tak jenuh tunggal (MUFA), asam lemak tak jenuh ganda (PUFA) dan kandungan total asam lemak. 


\section{Deteksi Keragaman Gen KIF12 melalui PCR-RFLP}

Ekstraksi DNA yang dilakukan mengacu pada metode phenol-chloroform menurut Sambrook \& Russel (2001). Titik mutasi gen KIF12 yang digunakan mengacu pada Listiyarini et al. (2018). Primer gen KIF12 yang digunakan memiliki Forward : 5'-CAC AGT GAG TGG ACT CAG AC -3'and dan titik Revese: 5'- GCT GCT ACG CCA TTG AAC AG -3)' yang didesain mengamplifikasi produk PCR 676 bp. Program PCR yang digunakan untuk mengamplifikasi produk PCR yaitu $95^{\circ} \mathrm{C}$ selama 5 menit. 35 siklus dengan masingmasing siklus $95{ }^{\circ} \mathrm{C}$ selama 10 detik, $62{ }^{\circ} \mathrm{C}$ selama 20 detik dan $72{ }^{\circ} \mathrm{C}$ selama 30 detik. Amplifikasi produk DNA DNA 676 bp divisualisasikan menggunakan agarose gel $1.5 \%$. Produk PCR kemudian dipotong menggunakan tekhnik PCR RFLP dengan menggunakan enzim $B f a I$ dengan cara diinkubasi pada suhu $37{ }^{\circ} \mathrm{C}$ selama 4 jam (Thermo Fisher Scientific, EU, Lithuana). Produk hasil PCR RFLP kemudian divisualisasikan menggunakan agarose gel $2 \%$.

\section{Analisis Statistik}

Analisis hubungan antara genotipe gen KIF12 terhadap asam lemak dilakukan menggunakan General Linier Model (GLM) using SAS. 9.2 softwere Model matematika yang digunakan sebagai berikut: $Y_{i j}=\mu+G_{i}+B j E_{i j k}$
Dimana: Yij $=$ nilai pengamatan pengaruh genotipe ke-i, ulangan ke $\mathrm{j} ; \mu=$ nilai tengah umum; $\mathrm{Gi}=$ pengaruh efek tetap genotipe $\mathrm{ke}-\mathrm{i}$; Bj pengaruh efek tetap rumpun $=(\mathrm{DEG}$, DET), Eijk= pengaruh galat percobaan ke-i,-j dan -k. Apabila ditemukan adanya perbedaan antar genotipe dilakukan perbandingan uji $t$ dan nilai pdikoreksi menggunakan koreksi TurkeyKramer (Kayan et al, 2011; Cinar et al, 2012).

\section{HASIL DAN PEMBAHASAN}

\section{Keragaman Gen KIF12 pada Domba}

Panjang produk PCR gen KIF12 sebesar 676 base pare (bp) berhasil diamplifikasi (Gambar 1). Hasil PCR RFLP menunjukkan tiga tipe genotipe berhasil diidentifikasi yaitu TT (553 bp dan 143 bp), genotipe CT (553 bp, 413 bp, $143 \mathrm{bp}$, dan $120 \mathrm{bp})$, dan genotipe CC (413 bp, $143 \mathrm{bp}$, dan $120 \mathrm{bp)}$ yang merupakan kombinasi dari alel $\mathrm{C}$ dan $\mathrm{T}$. Hasil pemotongan PCR RFLP gen KIF12 disajikan pada Gambar 2. Perubahan dari basa Cytosin (C) menjadi basa Timin (T) terjadi pada titik mutasi ke-7 469 dan 7 882. Teknik PCR RLFP didasarkan pada polimorfisme yang muncul karena adanya basa yang mengalami substitusi, penambahan, pengurangan dan perpindahan (translokasi) pada genom DNA. Perubahan tersebut menyebabkan perbedaan ukuran dari fragmen retriksi yang dicerna oleh enzim restriksi tertentu (Bardakci 2001).

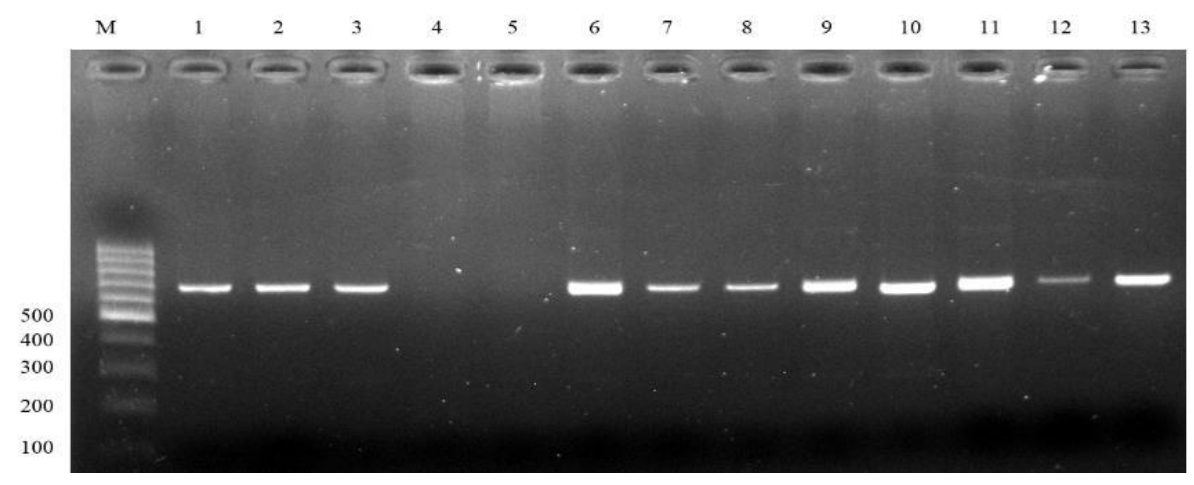

Gambar 1. Amplifikasi produk PCR gen KIF12 . M = 100 bp Marker standar; baris $1-13=$ sampel domba yang diuji 


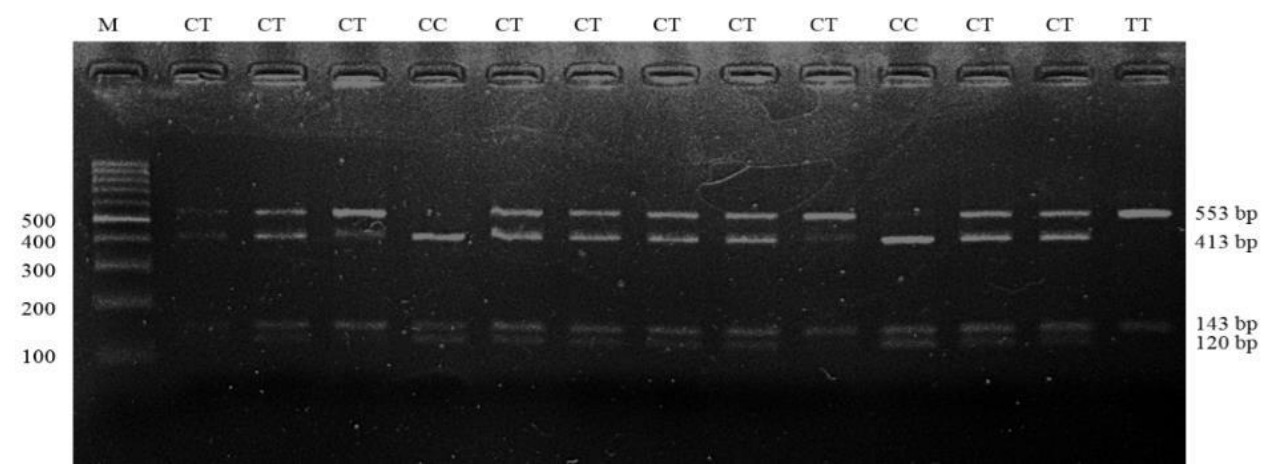

Gambar 2. Hasil pemotongan PCR-RFLP gen KIF12 menggunakan enzim BfaI.. M = 100bp markers. $1,2,3,5,6,7,8,9,11,12=$ genotipe $\mathrm{CT} ; 4,10=$ genotipe $\mathrm{CC} ; 13=$ genotipe TT

\section{Frekuensi Alel dan Genotipe Gen KIF12}

Ferkuensi alel CC, CT, dan TT masingmasing sebesar $0.15,0.6$, dan 0.25 untuk DEG dan $0.2,0.27$, dan 0.53 untuk DET. Frekuensi alel $\mathrm{C}$ dan $\mathrm{T}$ pada DEG masing-masing 0.45 dan 0.55 , sedangkan pada DET, alel C dan T masingmasing 0.33 dan 0.67 (Tabel 1).. Frekuensi alel yang diperoleh menunjukkan bahwa gen KIF12 bersifat polimorfik (beragam). Hal ini didasarkan pada pernyataan Nei dan Kumar (2000) bahwa gen dikatakan polimorfik apabila salah satu alelnya mempunyai frekuensi kurang dari 99\%. Noor (2010) menjelaskan bahwa keragaman gen dapat digunakan sebagai acuan dalam menentukan program pemuliaan yaitu dilakukan seleksi apabila populasi beragam dan persilangan dilakukan apabila populasi seragam.

Tabel 1 Frekuensi genotipe, frekuensi alel, dan keseimbangan Hardy-Weinberg

\begin{tabular}{cccccccc}
\hline \multirow{2}{*}{$\begin{array}{c}\text { Ternak } \\
\text { Domba }\end{array}$} & \multirow{2}{*}{$\mathrm{N}$} & \multicolumn{3}{c}{ Frekuensi Genotipe } & \multicolumn{2}{c}{ Frekuensi Alel } & \multirow{2}{*}{$\chi^{2}$} \\
\cline { 3 - 7 } & & $\mathrm{CC}$ & $\mathrm{CT}$ & $\mathrm{TT}$ & $\mathrm{C}$ & $\mathrm{T}$ & \\
\hline DET & 15 & $0.2(3)$ & $0.27(4)$ & $0.53(8)$ & 0.33 & 0.67 & 1.52 \\
DEG & 20 & $0.15(3)$ & $0.61(12)$ & $0.25(5)$ & 0.45 & 0.55 & 10.49 \\
Gabungan & 35 & $0.17(6)$ & $0.45(16)$ & $0.37(13)$ & 0.40 & 0.60 & 6.91 \\
\hline n: banyak sampel $()=$. banyak sampel yang bergenotipe CC,CT,TT; $\mathrm{x}^{2}$ tabel $(0.05)=3.84$
\end{tabular}

\section{Asosiasi Gen KIF12 Hubungannya dengan Asam Lemak pada Domba}

Analisis asosiasi gen KIF12 (g.9617965

$\mathrm{C}>\mathrm{T}$ ) terhadap asam lemak menunjukkan adanya hubungan yang signifikan $(\mathrm{P}<0.05)$ antara gen KIF12 dengan asam lemak jenuh (SFA) yaitu asam laurat (C12:0), asam miristat (C14:0), dan asam heptadekanoat (C17:0) serta asam lemak tak jenuh rangkap tunggal (MUFA) yaitu asam miristoleinat (C14:1) dan asam oleat (C18:1n9c). Asosiasi gen KIF12 terhadap asam lemak disajikan pada Tabel 2.

Domba dengan genotipe $\mathrm{CC}$ memiliki kandungan asam lemak tak jenuh miristoleinat (C14:1) lebih tinggi dibandingkan dengan genotipe CT dan TT, sedangkan genotipe CT memiliki kandungan asam lemak tak jenuh oleat (C18:1n9c) lebih tinggi dibandingkan dengan genotipe CC dan TT. Genotipe CT juga berasosiasi pada rendahnya asam lemak jenuh laurat (C12:0) dan asam miristat (C14:0), sedangkan genotipe TT berasosiasi pada rendahnya asam lemak jenuh heptadekanoat (C17:0). Asam miristolienat (C14:1) merupakan asam lemak tak jenuh tunggal yang dapat memberikan efek positif pada tubuh. Menurut Onkenhout et al., (1995), bahwa asam miristoleinat (C14:1) merupakan salah satu asam lemak omega-5 yang dibiosintesis dari asam miristat oleh enzim delta-9-desaturase. Keberadaan asam miristoleinat (C14:1) ini dapat dijadikan sebagai indikator diagnosa pada pasien yang mengalami oksidasi asam lemak rantai panjang. Asam lemak ini dikenal bersifat sitotoksik terhadap sel tumor serta dapat menginduksi apoptosis dan nekrosis pada sel kanker prostat pada manusia (Iguchi et al. 2001). Konsumsi daging yang mengandung asam lemak jenuh (SFA) tinggi terutama asam laurat (C12:0) diduga dapat mengakibatkan otot rentan terhadap resistensi insulin sehingga timbul hiperinsulinemia atau meningkatkan produksi kolesterol oleh hati (Cheeke dan Dierenfeld 
2010). Asupan tinggi dari asam lemak jenuh (SFA) dapat menyebabkan peningkatan kolesterol plasma, yang mengarah ke penyakit kardiovaskular.

Asam oleat $(\mathrm{C} 18: 1 \mathrm{n} 9 \mathrm{c})$ merupakan asam lemak yang mendominasi $(30.96 \pm 1.83)$ pada total MUFA $(32.87 \pm 1.98)$, terutama pada individu domba yang memiliki genotipe CT dibanding individu yang bergenotipe $\mathrm{CC}$ $(25.89 \pm 3.03)$ dan TT $(28.92 \pm 3.01)$ (Tabel 4). Selain itu, menurut penelitian Purbowati (2005), diketahui bahwa asam lemak tidak jenuh oleat memiliki kadar yang cukup tinggi dalam daging domba. Pada bobot potong $25-30 \mathrm{~kg}$, kadar asam tidak jenuh oleat mencapai 570.07-650.56 $\mathrm{mg} / 100 \mathrm{gr}$ daging domba. Asam oleat dikenal sebagai asam lemak omega-9. Asam lemak ini memiliki daya perlindungan tubuh yang mampu menurunkan kadar kolesterol Low Density Lipoprotein (LDL) dan meningkatkan kadar kolesterol High Density Lipoprotein (HDL).
HDL sering disebut sebagai kolesterol baik. Asam lemak tak jenuh tunggal (MUFA) lebih efektif menurunkan kadar kolesterol darah, daripada asam lemak tak jenuh jamak (PUFA) (Sartika 2008). Rai et al. (2017) menunjukkan bahwa kinesin mempunyai hubungan terhadap pengontrolan sekresi trigliserida dari hati. KIF12 secara transkripsi terkait dalam proses pembentukan asam lemak dan antioksidan dan menajdi target kritis kelebihan nutrisi pada sel beta (Yang et al, 2014). Hal ini menunjukkan bahwa gen KIF12 berperan penting dalam mengontrol metabolisme asam lemak didalam tubuh. Adanya penanda genetika molekuler pada domba lokal Indonesia bergenotipe CT dapat dijadikan kunci dalam seleksi domba sehat dengan kandungan asam lemak tak jenuh tinggi terutama pada asam oleat di masa yang akan datang. Meskipun demikian, asoasiasi ini harus dibuktikan dan divalidasi dalam populasi yang lebih besar.

Tabel 2. Asosisasi gen KIF12 hubungannya dengan komposisi asam lemak pada domba

\begin{tabular}{|c|c|c|c|}
\hline \multirow[b]{2}{*}{ Peubah } & \multicolumn{3}{|c|}{ Genotipe KIF12 } \\
\hline & $\begin{array}{c}\mathrm{CC}(6) \\
(\%)\end{array}$ & $\begin{array}{c}\mathrm{CT}(16) \\
(\%)\end{array}$ & $\begin{array}{c}\mathrm{TT}(13) \\
(\%)\end{array}$ \\
\hline Konten lemak (FC) & $6.31 \pm 3.80$ & $7.85 \pm 3.72$ & $5.44 \pm 2.95$ \\
\hline Asam lemak jenuh (SFA) & $39.88 \pm 5.95 a$ & $34.12 \pm 6.49 b$ & $39.39 \pm 3.94 a$ \\
\hline Asam kaprat (C10:0) & $0.14 \pm 0.04$ & $0.12 \pm 0.05$ & $0.11 \pm 0.05$ \\
\hline Asam laurat (C12:0) & $1.00 \pm 1.23 \mathrm{a}$ & $0.26 \pm 0.44 b$ & $0.63 \pm 0.57 \mathrm{ab}$ \\
\hline Asam miristat (C14:0) & $5.25 \pm 2.89 \mathrm{a}$ & $2.57 \pm 1.96 b$ & $4.52 \pm 1.75 b$ \\
\hline Asam pentadekonoat (C15:0) & $0.53 \pm 0.15$ & $0.51 \pm 0.19$ & $0.46 \pm 0.16$ \\
\hline Asam palmitat (C16:0) & $20.35 \pm 1.92$ & $18.51 \pm 2.91$ & $20.09 \pm 2.04$ \\
\hline Asam heptadekanoat (C17:0) & $1.00 \pm 0.28 \mathrm{~b}$ & $1.36 \pm 0.41 \mathrm{a}$ & $0.95 \pm 0.25 b$ \\
\hline Asam stearat (C18:0) & $11.53 \pm 1.94$ & $10.73 \pm 3.77$ & $12.54 \pm 2.89$ \\
\hline Asam arakidat $(\mathrm{C} 20: 0)$ & $0.08 \pm 0.03$ & $0.06 \pm 0.03$ & $0.08 \pm 0.03$ \\
\hline Asam lemak tidak jenuh (Unsaturated) & $30.25 \pm 2.93 b$ & $35.93 \pm 1.85 a$ & $33.62 \pm 3.85 a$ \\
\hline $\begin{array}{l}\text { Asam lemak tidak jenuh tunggal } \\
\text { (MUFA) }\end{array}$ & $27.91 \pm 3.16 \mathrm{a}$ & $32.87 \pm 1.98 b$ & $30.85 \pm 3.18 b$ \\
\hline Asam miristoleinat (C14:1) & $0.21 \pm 0.09 \mathrm{a}$ & $0.12 \pm 0.07 \mathrm{~b}$ & $0.17 \pm 0.06 \mathrm{ab}$ \\
\hline Asam palmitoleat (C16:1) & $1.82 \pm 0.40$ & $1.79 \pm 0.32$ & $1.76 \pm 0.29$ \\
\hline Asam oleat $(\mathrm{C} 18: \ln 9 \mathrm{c})$ & $25.89 \pm 3.03 b$ & $30.96 \pm 1.83 a$ & $28.92 \pm 3.01 \mathrm{a}$ \\
\hline $\begin{array}{l}\text { Asam lemak tidak jenuh ganda } \\
\text { (PUFA) }\end{array}$ & $2.34 \pm 0.77$ & $2.06 \pm 0.90$ & $2.76 \pm 1.50$ \\
\hline Asam elaidic $(\mathrm{C} 18: \ln 9 \mathrm{t})$ & $0.12 \pm 0.10$ & $0.13 \pm 0.10$ & $0.11 \pm 0.13$ \\
\hline Asam arakidonat (C20:4n6) & $0.37 \pm 0.29$ & $0.23 \pm 0.18$ & $0.42 \pm 0.26$ \\
\hline Asam linoleat (C18:2n6c) & $1.98 \pm 0.50$ & $1.83 \pm 0.67$ & $2.34 \pm 1.25$ \\
\hline Total asam lemak & $71.11 \pm 5.01$ & $70.29 \pm 5.95$ & $74.08 \pm 5.47$ \\
\hline
\end{tabular}




\section{KESIMPULAN}

Hasil identifikasi keragaman gen KIF12|BfaI (g.9617965 C>T) pada DEG dan DET bersifat polimorfik (beragam). Asosiasi gen KIF12 menunjukkan signifikan berasosiasi dengan kandungan asam lemak tak jenuh rangkap tunggal (MUFA) yaitu asam miristoleinat (C14:1) dan asam oleat (C18:1n9c) serta asam lemak jenuh (SFA) asam laurik (C12:0), asam miristik (C14: 0) and asam heptadenoik (C17: asam lemak jenuh (SFA) asam laurik (C12:0), asam miristik (C14: 0) and asam heptadenoik (C17: 0) 0). Asam lemak oleat merupakan asam lemak yang mendominasi pada total MUFA, terutama pada individu domba yang memiliki genotipe CT dibanding individu yang bergenotipe $\mathrm{CC}$ dan TT. Gen KIF12 berpotensi digunakan sebagai penanda genetik untuk asam lemak oleat (C18:1n9c) untuk mengahasilkan daging domba sehat dengan kandungan asam lemak tak jenuh tinggi pada domba lokal Indonesia.

\section{UCAPAN TERIMA KASIH}

Ucapan terima kasih disampaikan kepada Kementrrian Pertanian melalui Projek Penelitian KP4S yang telah membiaya penelitian ini dengan Nomor Kontrak: 76.60/PL.040/H.1/04/2017.K date 20 April 2017

\section{DAFTAR PUSTAKA}

Alvarenga, T.I.R.C., Y. Chen, I.F. FurushoGarcia, \& J.R.O. Perez. 2015. Manipulation of omega-3 PUFAs in lamb:phenotypic and genotypic views. Comprehensive Reviews in Food Science and Food Safety 14:189-204.

AOAC. 2012. Official Methods of Analysis. 19th Ed. Association of Official Analytical 240 Chemists. Washington, Arlington, USA.

Bardakci, F. 2001. Random amplified polymorphic DNA (RAPD) markers. Turk J Biol 25:185-196.

[DPKH] Direktorat Jenderal Peternakan dan Kesehatan Hewan. 2017. Statistik Peternakan. Direktorat Jenderal Peternakan dan Kesehatan Hewan. Kementerian Peternakan, RI. Jakarta (ID).
Cheeke P.R., \& E.S. Dierenfeld. 2010. Comparative Animal Nutrition and Metabolism. Cambridge (US): CABI Publ.

Kayan, A., M.U. Cinar, M.J. Uddin, C. Phatsara, K. Wimmers, S. Ponsuksili, D. Tesfaye, C. Looft, H. Juengs, E. Tholen, \& K. Schellander. 2011. Polymorphism and expression of the porcine Tenascin $\mathrm{C}$ gene associated with meat and carcass quality. Meat Sci. 89(1):76-83.

Kazakov A, G.W. Friars, \& J.D. Holt. 1984. Relationships of carcass fat and grade traits in broiler chickens. Can J Anim Sci. 64:613-620.

Listyarini, K., Jakaria'M. J. Uddin, C. Sumantri and A. Gunawan. Association and Expression of CYP2A6 and KIF12 Genes related to Lamb Flavour and Odour. Trop. Anim. Sci. J. 41(2):100107

Nei, M, \& S. Kumar. 2000. Molecular Evolution and Phylogenetics. Oxford Univ Pr. New York.

Noor RR. 2010. Genetika Ternak. Jakarta (ID): Penebar Swadaya. Jakarta.

Onkenhout, W, V. Venizelos, P.E. van der Poel, M.P. van den Heuvel, \& B.J. Poorthuis. 1995. Identification and quantification of Intermediates of unsaturated fatty acid metabolism in plasma of patients with fatty acid oxida-tion disorders. J Clinical Chemistry 41(10):1467-1474.

Purbowati, E, E. Baliarti, S.P.S. Budhi \& W. Lestariana. 2005. Profil asam lemak daging domba lokal jantan yang dipelihara di pedesaan pada bobot potong dan lokasi otot yang berbeda. Buletin Peternakan 29(2):62-70.

Rai, P, M. Kumara, G. Sharmab, P. Baraka, S. Dasb, S.S. Kamatcd, R. Mallika. 2017. Kinesin-dependent mechanism for controlling triglyceride secretion from the liver. PNAS. 114 (49):12958-12963.

Sambrook, J, E.F. Fritsch, \& J.F. Medrano. 1989. Molecular Cloning: a Laboratory Manual. Ed ke-2. Cold Spring Harbor Laboratory Pr. New York. 
Sartika RAD. 2008. Pengaruh asam lemak jenuh, asam lemak tidak jenuh dan asam lemak trans terhadap kesehatan. Jurnal Kesehatan Masyarakat Nasional 2(4): 154-160.

Wina, E, \& I.W.R. Susana. 2013. Manfaat lemak terproteksi untuk meningkatkan produksi dan reproduksi ternak ruminansia. Wartazoa 23(4):176-184.

Yang W, Tanaka Y, Bundo M, Hirokawa N. 2014. Antioksidant signaling involving the microtubule motor KIF12 is an intracellular target of nutrition excess in beta cells. Developmental Cell 31:202214. 